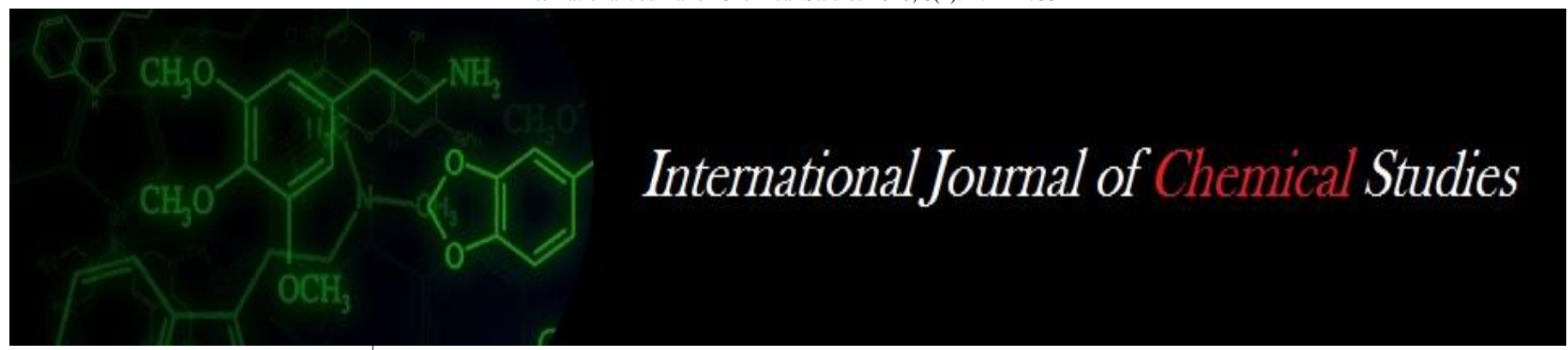

P-ISSN: 2349-8528

E-ISSN: 2321-4902

www.chemijournal.com

IJCS 2020; 8(1): 2741-2753

(C) 2020 IJCS

Received: 07-11-2019

Accepted: 09-12-2019

\section{MR Thakur}

Soil and Water Management,

NARP Phase II, Cotton

Research Sub Station, Navsari

Agricultural University,

Achhalia, Gujarat, India
Corresponding Author: MR Thakur

Soil and Water Management, NARP Phase II, Cotton Research Sub Station, Navsari

Agricultural University, Achhalia, Gujarat, India

\title{
Square formation, boll retention, yield and quality parameters of $B t$ and non-Bt cotton in relation to plant density and NPK levels
}

\section{MR Thakur}

DOI: https://doi.org/10.22271/chemi.2020.v8.i1ap.8685

\begin{abstract}
A Two year experiment was conducted to study the effect of plant densities and NPK levels on Bt and non-Bt cotton in split plot with four replications. The result shows that non-Bt cotton produced taller plant, more monopodia and sympodia, higher leaf area index (LAI). Whereas, Bt cotton had maximum specific leaf weight (SLW), net assimilation rate (NAR), square formation rate (SFR), fruit production efficiency (FPE), boll retention efficiency (BRE), boll growth rate, yield attributes and thus produced higher seed cotton yield than non-Bt. Bt cotton minimized the boll maturation period and impart earliness in cotton. The Bt cotton enhanced ginning out turn whereas, staple length and micronaire value remained higher in non-Bt. As regards plant density, spacing of $90 \times 60 \mathrm{~cm}$ recorded more monopodia and sympodia, maximum SLW, NAR, SFR, BRE, picked bolls and seed cotton yield per plant than $90 \times 45 \mathrm{~cm}$. On contrary higher plant density under $90 \mathrm{x} 45 \mathrm{~cm}$ spacing increased plant height, LAI, FPE and seed cotton yield per ha. Each increased level of NPK significantly increased plant height, number of monopodia, sympodia and LAI over lower level. The application of 75:37.5:37.5 $\mathrm{kg}$ NPK ha $^{-1}$ significantly increased SLW, NAR, SFR, FPE, BRE, boll growth rate, boll weight, picked bolls, seed cotton yield per ha and augment the lint quality traits like uniformity ratio and micronaire value over lowest level of NPK i.e. 50:25:25kg NPK ha-1. However, lowest level of NPK improved the lint elongation.
\end{abstract}

Keywords: Bt and non-Bt cotton, growth, square formation rate, boll retention efficiency, NPK levels, spacing

\section{Introduction}

Cotton is an important cash crop has been remained mainstay of millions of farmers in world as well as in India. The technological improvement in cotton cultivation like development of hirsutum hybrids, chemical means of pest control, use of chemical fertilizer on large scale and increase in area under irrigation has transformed India from importer to global exporter in raw cotton. This technological shift boosted Indian cotton productivity from mere $99 \mathrm{~kg} \mathrm{ha}^{-1}$ during 1950-51 to $302 \mathrm{~kg} \mathrm{ha}^{-1}$ during 2002-03, which accounts 205 per cent rise in five decades. However, spectacular rise of 160 to 180 per cent occurred in cotton productivity in just last one and half decade can be credited to Bt cotton and other technological step up. The development of Bt cotton, containing a genetically introgressed endotoxin gene from the gram negative soil bacteria (Bacillus thuringiensis Hubner) represents a significant technological landmark in the global cotton research and Indian cotton farming. Prior to the introduction of Bt cotton in India, about 40672 tonnes of pesticides were sprayed on this crop which occupied only 5 percent of the cultivated area (Bambawale and Jeyakumar, 2009) ${ }^{[4]}$. During the post $\mathrm{Bt}$ cotton era, between 2002 and 2006, there was significant reduction in the insecticide use to the tune of 9000 tons, valued approximately US\$ 80 million (ISAAA, 2009) ${ }^{[19]}$. Presently, out of total cotton area of 12.24 million ha in India 93 percent is covered by Bt cotton. Though the adoption of Bt cotton considerably increased Indian cotton productivity $\left(480 \mathrm{~kg} \mathrm{ha}^{-1}\right)$ but it is lower than major cotton growing countries like Australia $\left(1814 \mathrm{~kg} \mathrm{ha}^{-1}\right)$, China $\left(1726 \mathrm{~kg} \mathrm{ha}^{-1}\right)$, Brazil (1636)kg ha $\left.{ }^{-1}\right)$, Egypt (751 $\left.\mathrm{kg} \mathrm{ha}^{-1}\right)$ and Pakistan $\left(699 \mathrm{~kg} \mathrm{ha}^{-1}\right)$. In India majority of cotton grown under rainfed condition represents 65.10 per cent of total cotton cultivated area. The uncertain and erratic nature of rainfall in rainfed area adversely affect the growth (Sahito et al., 2015) ${ }^{[39]}$, proportion of vegetative and reproductive biomass (Hassan et al., 2016) ${ }^{[17]}$, square and boll setting by affecting assimilates supply to young fruiting bodies (Pettigrew, 2004) ${ }^{[30]}$, boll weight and finally yield. 
The Bt cotton known to differ in morphological, phenological and physiological characteristics than non-Bt (Chen et al., $2002^{[9]}$ and Thakur et al., 2017) ${ }^{[49]}$. Past studies revealed that Bt cotton hybrids had short stature (Mayee et al., $2004^{[26]}$ ) due to fever branches and smaller leaves (Sahai and Rahman, $2003{ }^{[38]}$ ), but retained more bolls at a early stage (Hebbar et al., $2007^{[18]}$ ) and more efficient in mobilizing photosynthates to sink (Prakash et al., $2008{ }^{[33]}$ ). This altered agronomic characteristics in $\mathrm{Bt}$ cotton provide opportunity to accommodate more number of plants per unit area and escape late season moisture stress occurred due to early withdrawal of monsoon in rainfed area and thereby increase cotton productivity per unit area. But retention of more bolls in $\mathrm{Bt}$ cotton at a early stage certainly needs more nutrients in a particular period. Thus taking into consideration the above aspect, this experiment was conducted for comparative assessment of $\mathrm{Bt}$ and no-Bt cotton in respect of growth, fruiting nature and its retention, boll characteristics, yield and quality at a different plant densities and NPK levels under rainfed situation.

\section{Materials and Methods}

This experiment was conducted at Cotton Research Unit, Dr. Panjabrao Deshmukh Krishi Vidyapeeth, Akola during 200809 and 2009-10. The experimental site was situated at $22^{\circ} 42^{\prime}$ $\mathrm{N}$ latitude and $77^{\circ} 02^{\prime} \mathrm{E}$ longitude with an altitude of 307.4 meters above the mean sea level. The climate of the site is hot during summer and general dryness throughout the year except during South-West monsoon. Soil of the experimental field was clayey in texture (Sand $24.15 \%$, Silt $26.50 \%$ and Clay $49.35 \%)$, slightly alkaline in reaction $(\mathrm{pH} \mathrm{8.15)}$, salt free $\left(\right.$ EC $\left.0.40 \mathrm{dSm}^{-1}\right)$, low in the organic carbon $(0.40 \%)$, available nitrogen $\left(150.53 \mathrm{~kg} \mathrm{ha}^{-1}\right)$ and available phosphorus $(15.97 \mathrm{~kg}$ $\mathrm{ha}^{-1}$ ) and fairly high in available potassium $\left(394.50 \mathrm{~kg} \mathrm{ha}^{-1}\right)$. Available sulphur content was $28.63 \mathrm{~kg} \mathrm{ha}^{-1}$, whereas available $\mathrm{Zn}, \mathrm{Fe}, \mathrm{Mn}$ and $\mathrm{Cu}$ were $0.610,5.574,8.327$ and $2.261 \mathrm{ppm}$, respectively. The experiment consisted of two cotton hybrids viz., Bt and non-Bt of same genotype NCS 145, two spacing viz., $90 \times 60 \mathrm{~cm}$ (recommended for non-Bt) and $90 \times 45 \mathrm{~cm}$ and three NPK levels viz., 50:25:25kg NPK $\mathrm{ha}^{-1}$ (recommended for non-Bt), 62.5:31.25:31.25kg NPK ha-1 and $75: 37.5: 37.5 \mathrm{~kg} \mathrm{NPK} \mathrm{ha}{ }^{-1}$. Experiment was layout in split plot design with four replications. Treatment combinations of cotton hybrids and spacing were allotted to main plots, whereas NPK levels were taken in subplots. Two seeds of cotton were dibbled at each point as per treatment in the first week of July, during both the years and after successful emergence, thinning was carried out to maintain single plant at each hill. Half of the $\mathrm{N}$ and full dose of $\mathrm{P}$ and $\mathrm{K}$ were applied as basal application at the time of sowing through urea, SSP and MOP, respectively and remaining half dose of $\mathrm{N}$ was top-dressed at 30 days after sowing (DAS) as per treatments. The fertilizers were side drilled $15 \mathrm{~cm}$ apart from crop row at $7.5 \mathrm{~cm}$ depth. Field was kept weed free during the period of experimentation. Similarly, necessary plant protection measures were carried out as and when population incidence of particular pest reached to ETL in a particular treatment.

The height of the main stem from the first basal node to the base of the last unfolded leaf, number of monopodia and sympodia of each of the five plants selected at random in the rows of net plot were recorded at a last picking and mean was worked out. The one plant in each plot taken at periodic interval for leaf dry matter and total dry matter was used for calculation of leaf area as per method described by Ashley et al. (1963) ${ }^{[2]}$. Specific leaf weight was calculated by dividing leaf dry weight with leaf area and expressed as $\mathrm{g} / \mathrm{dm}^{2}$. The net assimilation rate was calculated as per Williams (1946) ${ }^{[51]}$. The square formation rate indicates the rate of formation of new squares (fruiting positions) was calculated by following formula:

Square formation rate $\left(\right.$ No. of squares day $\left.{ }^{-1}\right)=\frac{\text { Total fruiting position at } \mathrm{P}_{2}-\mathrm{P}_{1}}{\mathrm{~T}_{2}-\mathrm{T}_{1}}$

Where, $\mathrm{P}_{2}$ and $\mathrm{P}_{1}$ are number of total fruiting positions at time $\mathrm{T}_{2}$ and $\mathrm{T}_{1}$ in days.

Whereas total fruiting positions include total aggregate number of squares, flowers and bolls including abscised and damaged fruiting bodies by bollworm up to stage of observation according to Wells and Meredith Jr. (1984) ${ }^{[50]}$. Fruit production efficiency indicates proportion of dry matter partitioned to reproductive structures out of total dry matter of plant was estimated with formula:

Fruit production efficiency $\left(\mathrm{g} \mathrm{kg}^{-1}\right.$ dry weight $)=\frac{\text { Weight of reproductive structures plant }}{-1}$

Boll retention efficiency was calculated at periodic interval by expressing number of intact bolls per plant as a percentage of total fruiting positions per plant. Boll maturation period indicate the time required in days from appearance of first flower to first boll split. Whereas, boll growth rate was calculated according to Reddy et al. (1999) ${ }^{[35]}$. Numbers of picked bolls on five observational plants were counted at each picking and average was determined. The average boll weight was calculated by dividing the total yield of five plants by total number of picked bolls from five observational plants. The seed cotton yield of each picking on five observational plants was measured and average was calculated to get per plant seed cotton yield. Earliness index was calculated by using Bartlett's formula as it was considered to be the most reliable method by Sivasubramanian (1962) ${ }^{\text {[44] }}$. Earliness index was assessed on the basis of weight of seed cotton obtained at each of the pickings in relation to total number of pickings.

$$
\text { Earliness index }=\frac{\left(P_{1}\right)+\left(P_{1}+P_{2}\right) \div-\cdots--\left(P_{1}+P_{2} \div \ldots P_{n}\right)}{n\left(P_{1}+P_{2}+\ldots-P_{n}\right)}
$$

Where, $\mathrm{P}_{1}, \mathrm{P}_{2}$ and $\mathrm{P}_{\mathrm{n}}$ are the weight of seed cotton collected in $1^{\text {st }}, 2^{\text {nd }}$ and $n^{\text {th }}$ pickings and ' $\mathrm{n}$ ' is total number of pickings taken.

Ginning out turn (\%) of different treatments was calculated by ginning $500 \mathrm{~g}$ of seed cotton picked from first picking. Fiber properties were studied based on $100 \mathrm{~g}$ lint obtained from first picking. The lint samples were analyzed at Ginning Training Centre, Central Institute for Research on Cotton Technology (ICAR), Nagpur, India. The statistical analysis of data was carried out as per method described by Gomez and Gomez $(1984)^{[14]}$.

\section{Result and Discussion Plant height}

Cotton being a crop of indeterminate growth habit continued to grow in height till its uprooting. Among cotton hybrids non-Bt recorded significantly highest plant height than $\mathrm{Bt}$ cotton (Table 1). The more boll load at early stage in $\mathrm{Bt}$ cotton diverted photosynthates towards bolls which might have break the apical dominance and thus impede plant height in Bt cotton hybrid. Similar differences in the plant height due 
to $\mathrm{Bt}$ and non-Bt cotton hybrids were reported by Ansingkar et al. (2005) ${ }^{[1]}$ and Srinivasulu et al. (2006) ${ }^{[46]}$. The spacing of $90 \times 45 \mathrm{~cm}$ resulted marked increase in plant height over $90 \times 60 \mathrm{~cm}$. The increased in plant height with increase in plant population per unit area was also observed by Singh et al. (2007) ${ }^{[42]}$. Increase in levels of NPK by and large increased the plant height progressively. This result attributed to more availability of nutrients with increase in the application rate, which might have increased all vital physiological processes, which in turn facilitated translocation of photosynthates to the growing meristematic tissues. This result corroborates the findings of Sisodia and Khamparia (2007) ${ }^{[43]}$.

\section{Number of monopodia and sympodia plant ${ }^{-1}$}

The non-Bt cotton produced significantly more number of monopodial and sympodial branches than Bt cotton (Table 1). The less number of monopodia and sympodia in Bt cotton might be because of more fruiting load at a early stage. As initiation of reproductive growth and it's timing with respect to vegetative development has large effect on production of growth structures. Srinivasan (2006) [45] also observed considerable reduction in number of monopodial and sympodial branches in Bt cotton over non-Bt. The wider spacing of $90 \mathrm{~cm} \times 60 \mathrm{~cm}$ recorded more numbers of sympodia and monopodia per plant than $90 \mathrm{~cm} x 45 \mathrm{~cm}$. Attenuation of light by top leaves of closely spaced cotton plants might have increased the intermodal length and consequently plant height to harness more solar radiation, thus most of the photosynthate consumed in vertical growth restricted horizontal structural growth under $90 \times 45 \mathrm{~cm}$ spacing. The more number of monopodia and sympodia per plant under low plant density was also reported by Bhalerao et al. $\left(2008^{\mathrm{a}}\right)$ ${ }^{[7]}$ and Reddy and Kumar (2010) ${ }^{[36]}$. Significant increase in a number of monopodia and sympodia per plant were noted with every successive increase in level of NPK. The linear response of cotton in respect of increased in number of monopodia and sympodia to every increased in level of NPK might be associated with increase in rate of morphogenesis and consequently production of more numbers of branches per plant. Earlier, Kalaichelvi (2009) ${ }^{[20]}$ also reported the beneficial effect of application of higher level of nutrients on the number of branches in cotton.

\section{Leaf area index (LAI)}

The $\mathrm{Bt}$ and non-Bt cotton hybrids differed significantly among themselves for LAI at all the stages of observations
(Table 1). The non-Bt cotton recorded significantly highest LAI over Bt cotton. Further it was also observed that difference in $\mathrm{Bt}$ and non $\mathrm{Bt}$ cotton in respect to LAI became more perceptible as the age of cotton crop advanced towards maturity where Bt cotton exhibited declined trend. Early retention of bolls and partitioning of more photosynthates towards sink might have reduced production of new leaves and consequently leaf area and LAI in Bt cotton. Significant reduction in LAI in Bt cotton hybrids over non-Bt cotton hybrids were also observed by Rekha (2007) ${ }^{[37]}$ and Gangaiah et al. (2013) ${ }^{[12]}$. The plants under $90 \times 45 \mathrm{~cm}$ spacing recorded significantly higher values of LAI over $90 \times 60 \mathrm{~cm}$. This indicates that narrow spaced cotton plant produced maximum leaf area per unit land area over wider spaced cotton plant. Nagender et al. (2017) ${ }^{[28]}$ also reported significantly highest LAI under closest plant spacing than wider. Each increase in the NPK level resulted in significant increase in LAI over its preceding lower level at all the stages of observations. The significant gain in LAI with increase in NPK level could be attributed to more number of functional leaves and thus leaf area because of improvement in NPK availability that facilitated the plant to grow vigorously. Similar effect of NPK levels on LAI was also observed by Sankaranarayanan et al. $(2011)^{[41]}$.

\section{Specific leaf weight (SLW)}

Kerby et al. (1980) ${ }^{[22]}$ opined that plant with higher SLW had more photosynthetic capability for dry matter production. Thus influence of spacing and NPK levels on SLW of Bt and non-Bt cotton was studied at 60,90 and 120 DAS (Table 2). Bt cotton hybrid recorded significantly higher value of specific leaf weight at 90 and 120 DAS than non-Bt cotton, however at 60 DAS result was non-significant. The leaves of the wider spaced $(90 \times 60 \mathrm{~cm})$ cotton plant recorded consistently significantly maximum SLW than narrow spaced $(90 \times 45 \mathrm{~cm})$ cotton leaves. Similar result was also reported by Pettigrew et al. (2013) ${ }^{[31]}$. As regard NPK levels, progressive increase in a specific leaf weight with increase in NPK level was observed at 60 DAS; however, at 90 and 120 DAS application of 75:37.5:37.5kg NPK ha-1 recorded significantly higher value in this respect but was at par with $62.5: 31.25: 31.25 \mathrm{~kg} \mathrm{NPK} \mathrm{ha}^{-1}$. Similar relation of SLW with N fertilization in cotton was reported earlier by Bondada and Oosterhuis (2001) ${ }^{[8] .}$

Table 1: Growth attributes of Bt and non Bt cotton as influenced by spacing and fertilizer levels (pooled of two years)

\begin{tabular}{|c|c|c|c|c|c|c|}
\hline \multirow{2}{*}{ Treatments } & \multirow{2}{*}{ Plant height (cm) } & \multirow{2}{*}{ No. of monopodia plant-1 } & \multirow{2}{*}{ No. of sympodia plant-1 } & \multicolumn{3}{|c|}{ Leaf area index } \\
\hline & & & & 60 DAS & 90 DAS & 120 DAS \\
\hline \multicolumn{7}{|c|}{ Cotton hybrids } \\
\hline Bt Cotton & $80.25 b$ & $1.37 \mathrm{~b}$ & $20.93 b$ & $0.545 \mathrm{~b}$ & $0.617 \mathrm{~b}$ & $0.532 \mathrm{~b}$ \\
\hline Non-Bt Cotton & $87.39 \mathrm{a}$ & $2.10 \mathrm{a}$ & $26.21 \mathrm{a}$ & $0.596 \mathrm{a}$ & $0.724 \mathrm{a}$ & $0.821 \mathrm{a}$ \\
\hline S. E. $(\mathrm{m}) \pm$ & 1.07 & 0.04 & 0.31 & 0.008 & 0.010 & 0.010 \\
\hline $\operatorname{LSD}(p=0.05)$ & 3.41 & 0.12 & 0.99 & 0.025 & 0.032 & 0.031 \\
\hline \multicolumn{7}{|c|}{ Spacing $(\mathbf{c m})$} \\
\hline $90 \times 60$ & $81.71 \mathrm{~b}$ & $1.93 \mathrm{a}$ & $24.84 \mathrm{a}$ & $0.505 \mathrm{~b}$ & $0.634 \mathrm{~b}$ & $0.609 \mathrm{~b}$ \\
\hline $90 \times 45$ & $85.93 \mathrm{a}$ & $1.55 \mathrm{~b}$ & $22.31 \mathrm{~b}$ & $0.636 \mathrm{a}$ & $0.707 \mathrm{a}$ & $0.744 \mathrm{a}$ \\
\hline S. E. $(\mathrm{m}) \pm$ & 1.07 & 0.04 & 0.31 & 0.008 & 0.010 & 0.010 \\
\hline $\operatorname{LSD}(p=0.05)$ & 3.41 & 0.12 & 0.99 & 0.025 & 0.032 & 0.031 \\
\hline \multicolumn{7}{|c|}{ NPK levels (kg ha-1) } \\
\hline $50: 25: 25$ & $80.66 \mathrm{~b}$ & $1.46 \mathrm{c}$ & $21.57 \mathrm{c}$ & $0.549 \mathrm{c}$ & $0.624 \mathrm{c}$ & $0.638 \mathrm{c}$ \\
\hline $62.5: 31.25: 31.25$ & $83.34 \mathrm{~b}$ & $1.71 \mathrm{~b}$ & $23.93 b$ & $0.570 \mathrm{~b}$ & $0.670 \mathrm{~b}$ & $0.676 \mathrm{~b}$ \\
\hline $75: 37.5: 37.5$ & $87.46 \mathrm{a}$ & $2.04 \mathrm{a}$ & $25.23 \mathrm{a}$ & $0.592 \mathrm{a}$ & $0.717 \mathrm{a}$ & $0.715 \mathrm{a}$ \\
\hline S.E. $(\mathrm{m}) \pm$ & 0.99 & 0.03 & 0.25 & 0.005 & 0.012 & 0.011 \\
\hline $\operatorname{LSD}(p=0.05)$ & 2.88 & 0.08 & 0.73 & 0.014 & 0.035 & 0.033 \\
\hline Mean & 83.82 & 1.73 & 23.57 & 0.571 & 0.670 & 0.677 \\
\hline
\end{tabular}

Means sharing different letters differ significantly at $p \leq 0.05$ 


\section{Net assimilation rate (NAR)}

NAR indicates the net gain of photosynthetic assimilates relative to leaf area and time. Even though the NAR differed significantly due to different treatment, it declined as the season progressed in all the treatment (Table 2). Among the cotton hybrids, Bt cotton recorded significantly highest NAR between 31-60 and 61-90 DAS; however, during 91-120 DAS corresponding result was obtained with non-Bt cotton. The higher values of NAR in Bt cotton at an initial stage was the result of retention of more numbers of bolls at an early stage compared to non-Bt. However, gain in NAR in non-Bt during 91-120 DAS might be the result of delayed boll setting because of considerable loss of fruiting bodies by bollworms. Wider spacing $(90 \times 60 \mathrm{~cm})$ resulted in highest NAR over narrow spacing $(90 \times 45 \mathrm{~cm})$ between $31-60$ and 61-90 DAS, whereas between 91-120 DAS the result was non-significant. This indicates that the shading of lower leaves at high LAI in closer spacing is partially responsible for the decrease in NAR. Furthermore, higher SLW under low plant density was responsible for higher NAR (Pettigrew and Meredith, 2012 ${ }^{[32]}$ ). NPK levels did the significant influence on NAR between 31-60 DAS only. The each increment in NPK level significantly increased the NAR at this stage.

Table 2: Specific leaf weight and net assimilation rate of Bt and non Bt cotton as influenced by spacing and fertilizer levels (pooled of two years)

\begin{tabular}{|c|c|c|c|c|c|c|}
\hline \multirow{2}{*}{ Treatments } & \multicolumn{3}{|c|}{ Specific leaf weight (g/ dm2) } & \multicolumn{3}{|c|}{ Net assimilation rate (NAR) (g/dm2/day) } \\
\hline & 60 DAS & 90 DAS & 120 DAS & 31-60 DAS & 61-90 DAS & 91-120 DAS \\
\hline \multicolumn{7}{|c|}{ Cotton hybrids } \\
\hline Bt Cotton & $0.981 \mathrm{a}$ & $1.334 \mathrm{a}$ & $1.361 \mathrm{a}$ & $0.2100 \mathrm{a}$ & $0.0921 \mathrm{a}$ & $0.0085 b$ \\
\hline Non-Bt Cotton & $1.015 \mathrm{a}$ & $1.245 \mathrm{~b}$ & $1.301 \mathrm{~b}$ & $0.1995 b$ & $0.0685 \mathrm{~b}$ & $0.0239 \mathrm{a}$ \\
\hline S. E. $(\mathrm{m}) \pm$ & 0.015 & 0.010 & 0.017 & 0.0031 & 0.0026 & 0.0026 \\
\hline $\operatorname{LSD}(p=0.05)$ & NS & 0.032 & 0.056 & 0.0098 & 0.0083 & 0.0082 \\
\hline \multicolumn{7}{|c|}{ Spacing (cm) } \\
\hline $90 \times 60$ & $1.073 \mathrm{a}$ & $1.351 \mathrm{a}$ & $1.431 \mathrm{a}$ & $0.2139 \mathrm{a}$ & $0.0857 \mathrm{a}$ & $0.0155 \mathrm{a}$ \\
\hline $90 \times 45$ & $0.923 b$ & $1.228 \mathrm{~b}$ & $1.230 \mathrm{~b}$ & $0.1957 b$ & $0.0748 \mathrm{~b}$ & $0.0170 \mathrm{a}$ \\
\hline S. E. $(\mathrm{m}) \pm$ & 0.015 & 0.010 & 0.017 & 0.0031 & 0.0026 & 0.0026 \\
\hline $\operatorname{LSD}(p=0.05)$ & 0.048 & 0.032 & 0.056 & 0.0098 & 0.0083 & NS \\
\hline \multicolumn{7}{|c|}{ NPK levels (kg ha-1) } \\
\hline $50: 25: 25$ & $0.822 \mathrm{c}$ & $1.196 \mathrm{~b}$ & $1.212 \mathrm{~b}$ & $0.1765 \mathrm{c}$ & $0.0790 \mathrm{a}$ & $0.0177 \mathrm{a}$ \\
\hline $62.5: 31.25: 31.25$ & $1.030 \mathrm{~b}$ & $1.311 \mathrm{a}$ & $1.360 \mathrm{a}$ & $0.2117 \mathrm{~b}$ & $0.0806 \mathrm{a}$ & $0.0151 \mathrm{a}$ \\
\hline $75: 37.5: 37.5$ & $1.142 \mathrm{a}$ & $1.362 \mathrm{a}$ & $1.421 \mathrm{a}$ & $0.2262 \mathrm{a}$ & $0.0812 \mathrm{a}$ & $0.0158 \mathrm{a}$ \\
\hline S. E. $(\mathrm{m}) \pm$ & 0.021 & 0.036 & 0.026 & 0.0037 & 0.0022 & 0.0025 \\
\hline $\operatorname{LSD}(p=0.05)$ & 0.060 & 0.104 & 0.076 & 0.0108 & NS & NS \\
\hline Mean & 0.998 & 1.290 & 1.331 & 0.2048 & 0.0803 & 0.0162 \\
\hline
\end{tabular}

Means sharing different letters differ significantly at $p \leq 0.05$

NS: Non significant

The relation between LAI and NAR (Figure 1) indicates that NAR increased up to $0.4 \mathrm{LAI}$ and declined thereafter in nonBt cotton. Whereas in Bt cotton NAR increased consistently in accordance with LAI. The consistent increased in NAR in according to LAI in $\mathrm{Bt}$ cotton attributed to successful conversion of most of the newly formed squares in developed bolls; on the contrary in non-Bt cotton bollworm infestation caused its significant loss (Thakur et al. $2018^{[48]}$ ). Specific leaf weight has also showed the marked influence on NAR (Figure 2); in both Bt and non-Bt cotton NAR increased with increasing specific leaf weight up to the value of 0.9 and 0.8 , respectively and decline thereafter. The LAI and SLW can be used successfully to predict NAR in cotton.

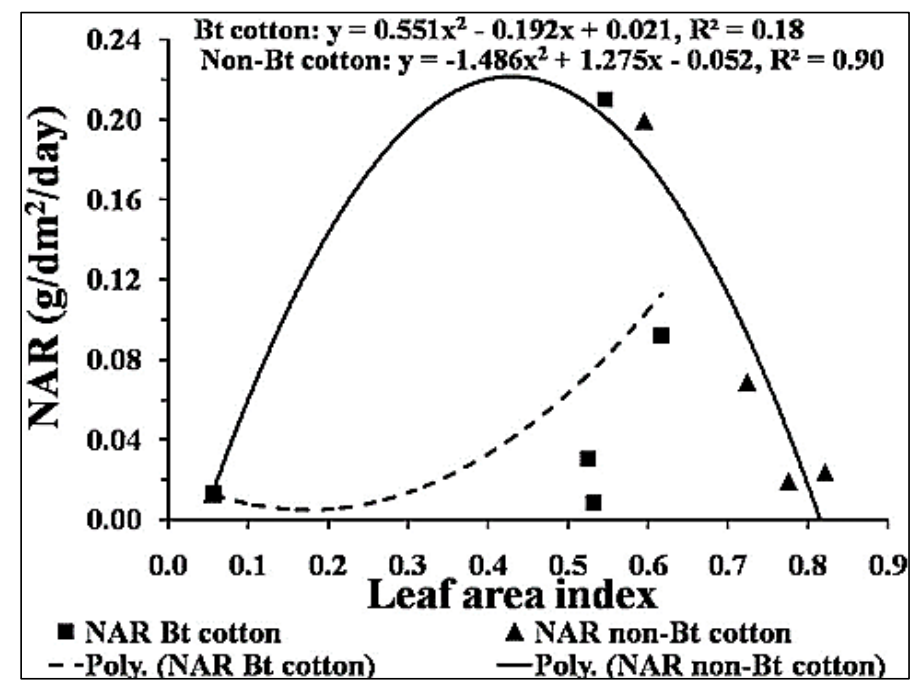

Fig 1: Relation between leaf area index and net assimilation rate 


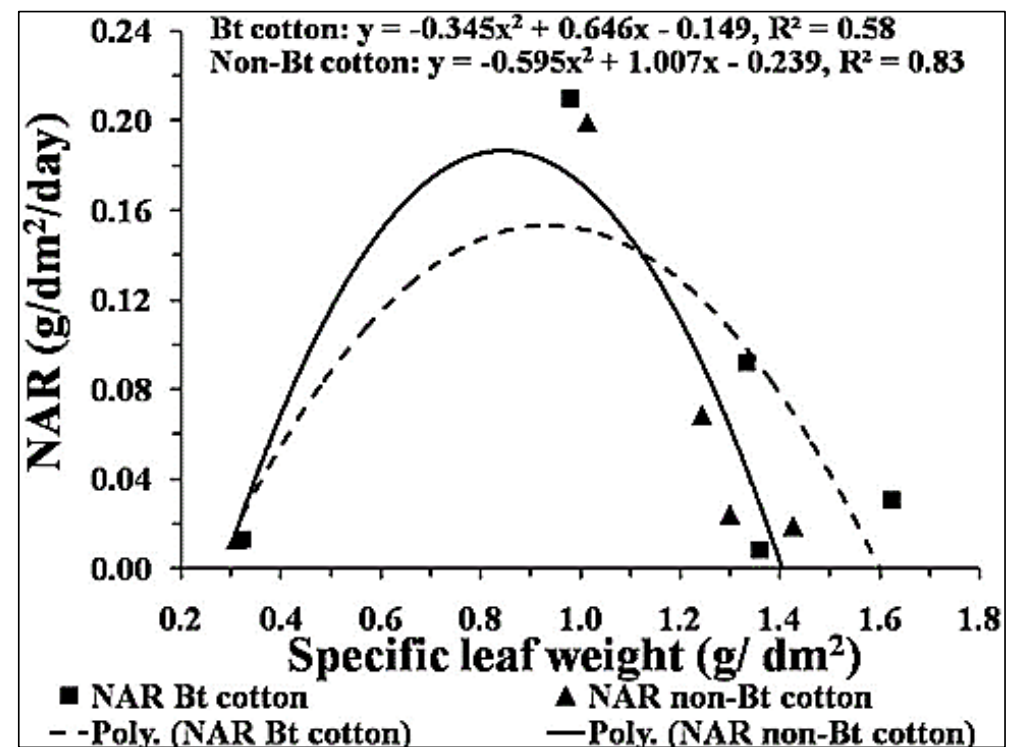

Fig 2: Relation between specific leaf weight and net assimilation rate.

\section{Square formation rate (SFR)}

The square formation rate which indicates the capacity of cotton plant to form new square as influenced by different treatments is depicted in Figure 3. The SFR was significantly higher in Bt cotton at a early stage i.e. between 41-61 DAS than non-Bt cotton. Whereas at subsequent stages the corresponding result was obtained with non-Bt cotton (Figure $3 a)$. The significant declined in rate of square formation in $\mathrm{Bt}$ cotton at later stages might be the result of conversion of more numbers of squares to bolls and its successful retention in $\mathrm{Bt}$ cotton. Thus resulted in intra plant competition for photosynthates within retained fruiting bodies in Bt cotton which restricts the formation of new sympodia and consequently new squares. On the contrary because of less boll setting due to bollworm damage, non-Bt cotton put forth the new growth continuously in latter stages and maintained higher SFR than Bt cotton. The spacing did the significant influenced on SFR during 41-61 DAS only (Figure 3b). The spacing of $90 \times 60 \mathrm{~cm}$ recorded higher SFR during this stage than $90 x 45 \mathrm{~cm}$. Levels of NPK significantly influenced the SFR at a different growth stages, except during 61-89 DAS (Figure 3c). However, the influence of NPK levels on SFR was not consistent during different growth stages of cotton. During 41-61 DAS each increase in NPK level significantly increased the rate of square formation over its preceding lower level. Whereas during 89-117 and 152-194 DAS application of 50:25:25kg NPK ha-1 showed maximum SFR over subsequent higher levels of NPK. During 117-152 DAS application of 75:37.5:37.5kg NPK ha-1 recorded significantly maximum SFR over $50: 25: 25 \mathrm{~kg}$ NPK ha-1 but was at par with $62.5: 31.25: 31.25 \mathrm{~kg}$ NPK ha-1.
Fruit production efficiency (FPE)

Fruit production efficiency is the dry weight of fruiting structures per total dry weight of plant, indicates proportion of dry matter partitioned to reproductive parts. Data depicted in Figure 4 showed that FPE increased as crop advanced towards maturity. This was due to gain in bolls weight per plant. The FPE was significantly higher in Bt cotton at all the stages of growth than non-Bt (Figure 4a). This was the result of retention of more numbers of bolls in Bt cotton at a early stage than non-Bt. Tayade and Dhbale (2009) ${ }^{[47]}$ also reported that $\mathrm{Bt}$ cotton partitioned more dry matter towards bolls than non-Bt. The spacing of $90 \times 45 \mathrm{~cm}$ effectively partitioned dry matter towards fruiting structures and recorded significantly higher value of FPE over $90 \times 60 \mathrm{~cm}$ at 61,152 and 194 DAS; however, at 89 and 117 DAS the result fails to attain the level of significance (Figure 4b). Proportionate increase in reproductive dry matter with increase in the plant density was also noted by Hakoomat et al. (2009) ${ }^{[15]}$. The levels of NPK did the significant influence on FPE at 61, 117 and 152 DAS (Figure 4c). At an initial stage i.e. 61 DAS application of $75: 37.5: 37.5$ and $62.5: 31.25: 31.25 \mathrm{~kg}$ NPK ha-1 were equally effective for increasing fruit production efficiency over $50: 25: 25 \mathrm{~kg}$ NPK ha- 1 . However, the trend among the NPK levels changed with the advancement of cotton crop to maturity. At 117 and 152 DAS application of 50:25:25kg NPK ha-1 recorded significantly higher value of fruit production efficiency over $75: 37.5: 37.5 \mathrm{~kg}$ NPK ha-1 but was at par with $62.5: 31.25: 31.25 \mathrm{~kg}$ NPK ha-1 at 117 DAS. This shift in trend and declined in the fruit production efficiency at later stages may be attributed to proportionate increase in vegetative growth with increase in NPK application rate. 

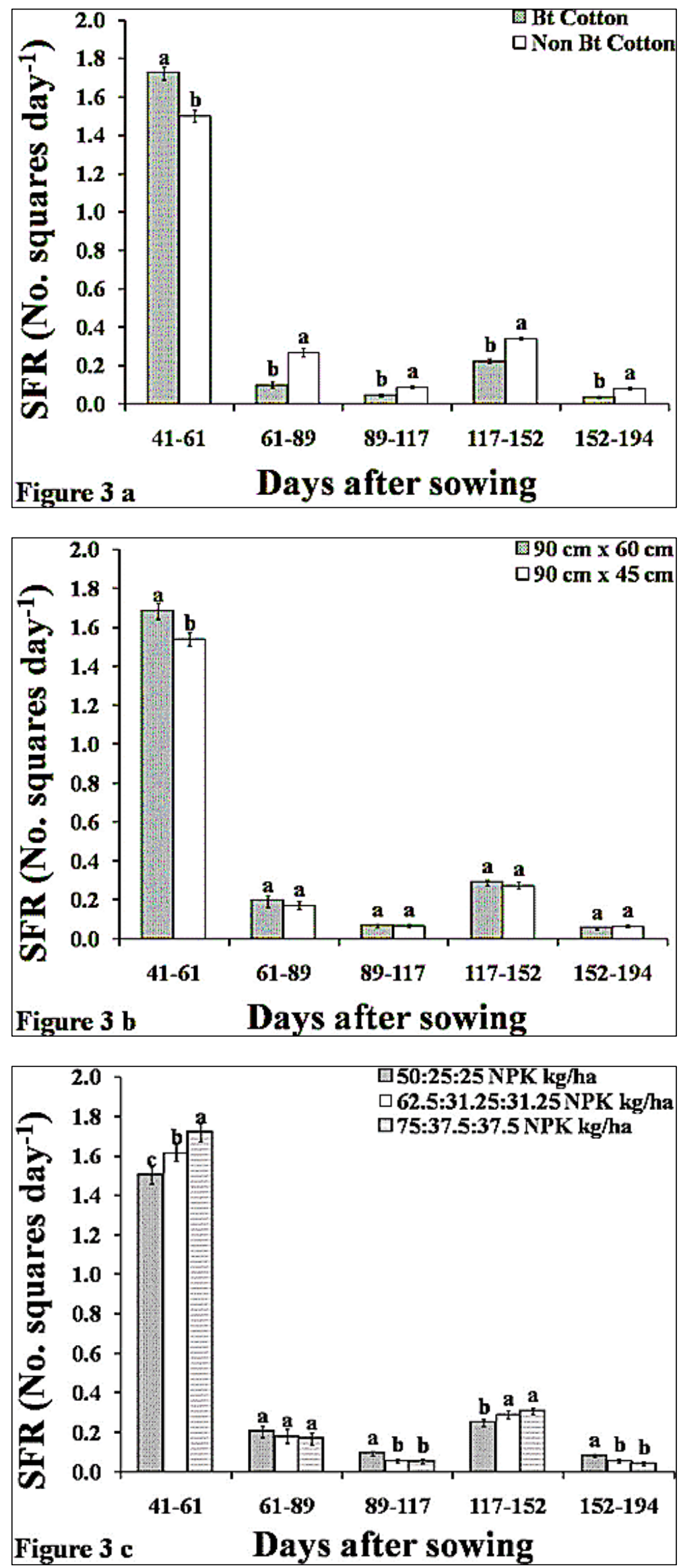

Fig 3: Square formation rate (SFR) as influenced by Bt and non-Bt cotton, spacing and NPK levels at different crop growth stages (pooled of two years). 

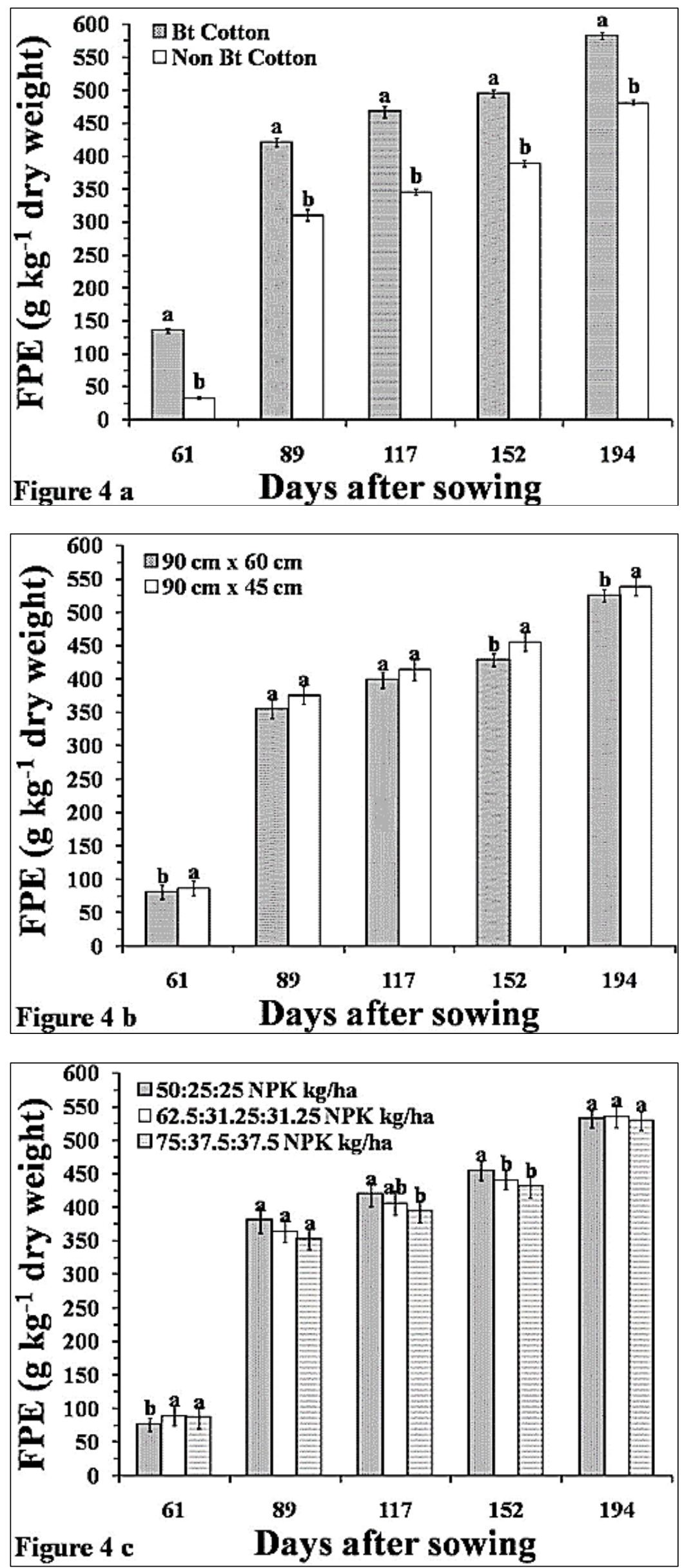

Fig 4: Fruit production efficiency (FPE) as influenced by Bt and non-Bt cotton, spacing and NPK levels at different crop growth stages (pooled of two years).

Error bars indicate SE \pm . The same letter indicates no significant difference $(p=0.05)$. 

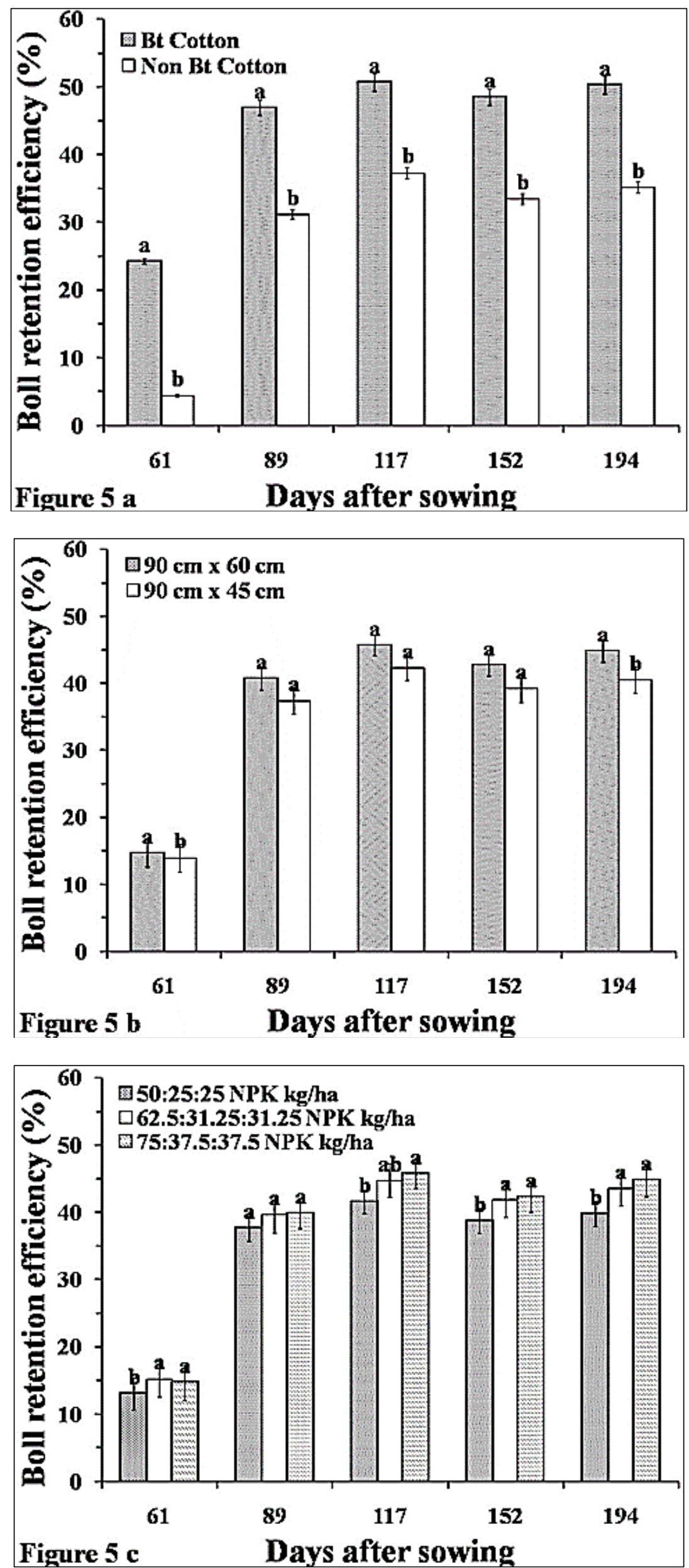

Fig 5: Boll retention efficiency as influenced by Bt and non-Bt cotton, spacing and NPK levels at different crop growth stages (pooled of two years). Error bars indicate SE \pm . The same letter indicates no significant difference $(p=0.05)$. 


\section{Boll retention efficiency (BRE)}

Boll retention efficiency indicates the percent of intact bolls on the plant to total fruiting positions formed (Figure 5). Overall boll retention efficiency increased up to 117 DAS, but thereafter decreased slightly; this indicates poor boll setting from newly formed squares which might be because of more competition within existing bolls for assimilates. Among the cotton hybrids Bt cotton recorded significantly higher value of BRE at all the stages of observation over non-Bt cotton (Figure 3a). Further it is interesting to note that difference between $\mathrm{Bt}$ and non-Bt cotton in respect of BRE was wide at an initial stage (61 DAS) and it narrowed down as the crop progressed towards senescence. This might be because of conversion of considerable number of squares to bolls at an early stage of fruiting in $\mathrm{Bt}$ cotton due to less damage to fruiting structures by bollworm than non-Bt. Rao and Alapati (2007) ${ }^{[34]}$ also narrated that $\mathrm{Bt}$ cotton retains more bolls than non-Bt at an early stage. The spacing of $90 \times 60 \mathrm{~cm}$ significantly increased the BRE over $90 \times 45 \mathrm{~cm}$ at all the stages of observations. This indicates the benefit of soil moisture and nutrient to individual plant under lower plant density because of less competition. The increased in boll retention with decrease in the plant density was also reported by Munir et al. (2015) ${ }^{[27]}$. Among NPK levels, application of $75: 37.5: 37.5 \mathrm{~kg}$ NPK ha-1 recorded significantly higher value of BRE over $50: 25: 25 \mathrm{~kg}$ NPK ha-1 but was at par with 62.5:31.25:31.25kg NPK ha-1 at all the growth stages. This might be attributed to mobilization and accumulation of assimilates in newly formed bolls with increase in availability of NPK; as NPK plays a major role in leaf area development and assimilate synthesis. Moreover, cell walls thickening in peduncle of developed bolls avert the formation of the abscission layer (Crozat et al. $1999^{[10]}$ ) and consequently boll drop. Increased in number of bolls per plant with increase in $\mathrm{N}$ application was observed by Ayissaa and Kebedeb, (2011) [3]

\section{Boll growth rate and boll maturation period}

The data presented in Table 3 showed that Bt cotton had significantly higher boll growth rate and required significantly less number of days for boll maturation than non-Bt cotton. This may be because of retention of early formed squares on lower canopy and its successful conversion in to bolls in $\mathrm{Bt}$ cotton hybrid which acquired the benefit of soil moisture as it is limiting factor at later stages of cotton growth under rainfed condition. The effect of spacing on boll growth rate and boll maturation period was non-significant. In case of NPK levels, application of $75: 37.5: 37.5 \mathrm{~kg}$ NPK ha-1 significantly hastened the boll growth rate over 50:25:25kg NPK ha-1 but was at par with $62.5: 31.25: 31.25 \mathrm{~kg}$ NPK ha-1. This result indicates that proper plant nutrition increases the rate of boll development process indirectly through its direct role in assimilates synthesis and its translocation to sink. Boll maturation period remained unchanged due to NPK levels.

Table 3: Yield attributes, yield and earliness in Bt and non Bt cotton as influenced by spacing and fertilizer levels (pooled of two years)

\begin{tabular}{|c|c|c|c|c|c|c|c|}
\hline Treatments & \begin{tabular}{|c} 
Boll growth rate \\
(mg day-1)
\end{tabular} & $\begin{array}{c}\text { Boll maturation } \\
\text { period (days) }\end{array}$ & $\begin{array}{l}\text { No. of picked } \\
\text { bolls plant-1 }\end{array}$ & $\begin{array}{c}\text { Average boll } \\
\text { weight (g) }\end{array}$ & $\begin{array}{c}\text { Seed cotton yield } \\
\text { plant-1 (g) }\end{array}$ & \begin{tabular}{|c|}
$\begin{array}{c}\text { Seed cotton yield } \\
\text { (kg ha-1) }\end{array}$ \\
\end{tabular} & $\begin{array}{c}\text { Earliness } \\
\text { index }\end{array}$ \\
\hline \multicolumn{8}{|c|}{ Cotton hybrids } \\
\hline Bt Cotton & $81.03 a$ & $46.40 \mathrm{~b}$ & $20.78 \mathrm{a}$ & $3.74 \mathrm{a}$ & $52.62 \mathrm{a}$ & $1019.68 \mathrm{a}$ & $0.85 a$ \\
\hline Non-Bt Cotton & $69.28 \mathrm{~b}$ & $55.88 \mathrm{a}$ & $17.23 \mathrm{~b}$ & $3.85 a$ & $44.87 \mathrm{~b}$ & $900.39 b$ & $0.71 \mathrm{~b}$ \\
\hline S. E. $(\mathrm{m}) \pm$ & 1.01 & 0.51 & 0.40 & 0.04 & 0.86 & 13.20 & 0.01 \\
\hline $\operatorname{LSD}(p=0.05)$ & 3.23 & 1.62 & 1.29 & NS & 2.75 & 42.22 & 0.04 \\
\hline \multicolumn{8}{|c|}{ Spacing (cm) } \\
\hline $90 \times 60$ & $75.31 \mathrm{a}$ & $51.13 \mathrm{a}$ & $20.72 \mathrm{a}$ & $3.80 \mathrm{a}$ & $51.81 \mathrm{a}$ & $902.05 b$ & $0.78 \mathrm{a}$ \\
\hline $90 \times 45$ & $74.99 \mathrm{a}$ & $51.15 \mathrm{a}$ & $17.29 \mathrm{~b}$ & $3.79 \mathrm{a}$ & $45.68 \mathrm{~b}$ & $1018.03 a$ & $0.78 \mathrm{a}$ \\
\hline S. E. $(\mathrm{m}) \pm$ & 1.01 & 0.51 & 0.40 & 0.04 & 0.86 & 13.20 & 0.01 \\
\hline $\operatorname{LSD}(p=0.05)$ & NS & NS & 1.29 & NS & 2.75 & 42.22 & NS \\
\hline \multicolumn{8}{|c|}{ NPK levels (kg ha-1) } \\
\hline $50: 25: 25$ & $73.59 \mathrm{~b}$ & $51.03 \mathrm{a}$ & $17.22 \mathrm{~b}$ & $3.71 \mathrm{~b}$ & $44.69 \mathrm{~b}$ & $918.63 b$ & $0.79 a$ \\
\hline $62.5: 31.25: 31.25$ & $75.42 \mathrm{ab}$ & $51.06 \mathrm{a}$ & $19.39 \mathrm{a}$ & $3.80 \mathrm{ab}$ & $50.38 \mathrm{a}$ & $976.96 a$ & $0.78 \mathrm{a}$ \\
\hline $75: 37.5: 37.5$ & $76.45 \mathrm{a}$ & $51.31 \mathrm{a}$ & $20.39 a$ & $3.88 \mathrm{a}$ & $51.16 \mathrm{a}$ & $984.52 \mathrm{a}$ & $0.78 \mathrm{a}$ \\
\hline S. E. $(\mathrm{m}) \pm$ & 0.64 & 0.22 & 0.34 & 0.03 & 0.98 & 14.16 & 0.01 \\
\hline LSD $(p=0.05)$ & 1.86 & NS & 1.00 & 0.09 & 2.86 & 41.33 & NS \\
\hline Mean & 75.15 & 51.14 & 19.00 & 3.80 & 48.74 & 960.04 & 0.78 \\
\hline
\end{tabular}

Means sharing different letters differ significantly at $\mathrm{p} \leq 0.05$

NS: Non significant

A strong positive relationship was existed between NAR and boll growth rate with slope increased with increasing NAR in both Bt and non-Bt cotton (Figure 6) indicating that NAR could be used as an index of boll growth rate in cotton. 


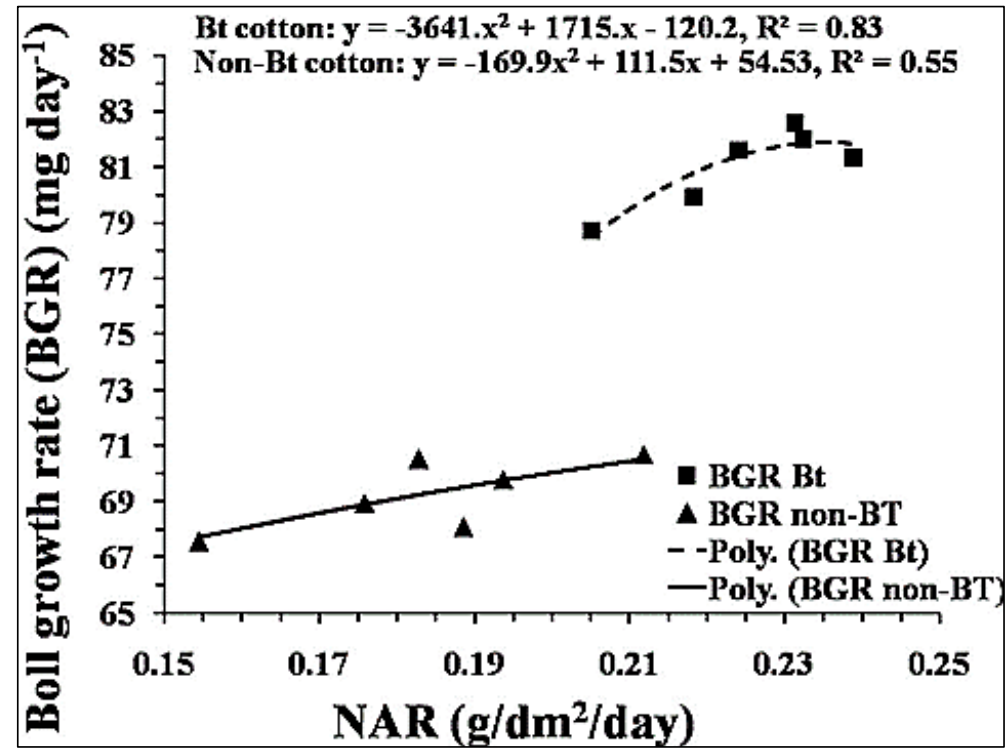

Fig 6: Relation between boll growth rate and net assimilation rate.

Number of picked bolls per plant and average boll weight Data in respect of number of picked bolls per plant and average boll weight are presented in Table 3. The number of picked bolls per plant is a function of square formation rate and boll retention efficiency which is primarily depends on photosynthetic efficiency of plant. Whereas efficient translocation of photosynthates from source to sink govern the boll weight. Bt cotton established its superiority by recording significantly more number of picked bolls per plant as compared to non Bt. The significant improvement in number of picked bolls per plant in Bt cotton associated with inbuilt resistance to bollworms, which enabled the crop to escape attack of bollworms and reached to boll bursting stage earlier than non-Bt. Patil et al. (2009) ${ }^{[29]}$ also recorded more number of picked bolls per plant in Bt cotton over its counterpart nonBt. The wider row spacing $(60 \mathrm{~cm})$ recorded significantly more number of picked bolls per plant than narrow row spacing $(45 \mathrm{~cm})$. The significant increase in number of picked bolls per plant attributed to more number of sympodial branches and increased growth attributes in wider spaced cotton plants. This result is in conformity with the findings of Bhalerao et al. (2008a) [7] who also reported significant increase in bolls per plant with decrease in the plant density. An application of 75:37.5:37.5kg NPK ha-1 established its significance over application of $50: 25: 25 \mathrm{~kg}$ NPK ha-1 by recording more numbers of picked bolls per plant, but it was at par with $62.5: 31.25: 31.25 \mathrm{~kg}$ NPK ha-1. The increased in number of picked bolls per plant with application of 75:31.25:31.25kg NPK ha-1 over 50:25:25kg NPK ha-1 was associated with improvement in growth attributes viz., plant height, number of sympodial branches, leaf area, specific leaf weight and net assimilation rate. The cumulative effect of these finally improved number of picked bolls per plant. Similar advantage of higher level of NPK in improving the number of picked bolls per plant was reported earlier by Bhalerao and Gaikwad (2010) ${ }^{[5]}$.

Cotton hybrids and spacing did not show the significant influence on average boll weight. Whereas application of 75:37.5:37.5kg NPK ha-1 significantly improved the average boll weight over 50:25:25kg NPK ha-1 but was on par with 62.5:31.25:31.25kg NPK ha-1. The present results are in line with the findings of Giri et al. (2008) ${ }^{[13]}$.

\section{Seed cotton yield}

Data presented in Table 3 in respect of seed cotton yield per plant and per ha showed that Bt cotton secured higher seed cotton yield per plant and per ha over non-Bt counterpart. The significant improvement in yield in Bt cotton was the result of increased in boll retention and thereby number of picked bolls per plant. The higher seed cotton yield in Bt cotton were also reported by Manjunatha et al. (2010) ${ }^{[24]}$ and Kaur et al. (2019) ${ }^{[21]}$. Spacing of $90 \times 60 \mathrm{~cm}$ recorded significantly higher seed cotton yield per plant over $90 \times 45 \mathrm{~cm}$. However, closer plants spacing of $90 \times 45 \mathrm{~cm}$ compensate per plant yield losses and recorded significantly higher seed cotton yield over wider spacing of $90 \times 60 \mathrm{~cm}$. Similar result was also reported by Munir et al. (2015) ${ }^{[27]}$ and Nagender et al. (2017) ${ }^{[28]}$. The application of $75: 37.5: 37.5 \mathrm{~kg}$ NPK ha-1 recorded significantly higher seed cotton yield per plant and per ha over $50: 25: 25 \mathrm{~kg}$ NPK ha-1 but was found to be at par with $62.5: 31.25: 31.25 \mathrm{~kg}$ NPK ha-1. The gain in seed cotton yield in this treatment ascribed to significant increase in number of picked bolls per plant and average boll weight. Similar trend in seed cotton yield with increase in NPK levels were reported by Bhalerao et al. (2008b) ${ }^{[6]}$ and Kumara et al. (2014) ${ }^{[23]}$.

\section{Earliness index}

Data presented in Table 3 revealed that earliness index differed significantly due to cotton hybrids only. Bt cotton hybrid was considerably earlier, recorded highest value of earliness index than non-Bt. Mayee and Rao (2002) [25] concluded that retention of early formed fruiting structures due to inbuilt resistance to bollworms lead to pronounce earliness in Bt cotton. Similarly, Deosarkar et al. (2004) [11] and Tayade and Dhbale (2009) [47] also noticed the pronounced earliness in Bt cotton. The effect of spacing and fertilizer levels on earliness index were non-significant. 
Table 4: Fiber quality parameters of Bt and non Bt cotton as influenced by spacing and fertilizer levels (pooled of two years)

\begin{tabular}{|c|c|c|c|c|c|c|}
\hline Treatments & $\begin{array}{c}\text { Ginning out turn } \\
(\%)\end{array}$ & $\begin{array}{c}2.5 \% \text { staple length } \\
(\mathrm{mm})\end{array}$ & Uniformity ratio $(\%)$ & $\begin{array}{c}\text { Micronaire value } \\
(10-6 \text { g inch-1) }\end{array}$ & $\begin{array}{c}\text { Bundle strength } \\
(\mathrm{g} \text { tex-1) }\end{array}$ & Elongation (\%) \\
\hline \multicolumn{7}{|c|}{ Cotton hybrids } \\
\hline Bt Cotton & $36.50 \mathrm{a}$ & $28.85 b$ & $49.33 \mathrm{a}$ & $4.10 \mathrm{~b}$ & $21.61 \mathrm{a}$ & $5.64 a$ \\
\hline Non-Bt Cotton & $36.00 \mathrm{~b}$ & $29.76 \mathrm{a}$ & $49.21 \mathrm{a}$ & $4.36 \mathrm{a}$ & $22.10 \mathrm{a}$ & $5.59 \mathrm{a}$ \\
\hline S. E. $(\mathrm{m}) \pm$ & 0.15 & 0.14 & 0.12 & 0.03 & 0.23 & 0.04 \\
\hline $\operatorname{LSD}(p=0.05)$ & 0.48 & 0.46 & NS & 0.11 & NS & NS \\
\hline \multicolumn{7}{|c|}{ Spacing $(\mathbf{c m})$} \\
\hline $90 \times 60$ & $36.24 \mathrm{a}$ & $29.32 \mathrm{a}$ & $49.19 \mathrm{a}$ & $4.20 \mathrm{a}$ & $22.01 \mathrm{a}$ & $5.60 \mathrm{a}$ \\
\hline $90 \times 45$ & $36.27 \mathrm{a}$ & $29.29 \mathrm{a}$ & $49.35 \mathrm{a}$ & $4.25 \mathrm{a}$ & $21.70 \mathrm{a}$ & $5.62 \mathrm{a}$ \\
\hline S. E. $(\mathrm{m}) \pm$ & 0.15 & 0.14 & 0.12 & 0.03 & 0.23 & 0.04 \\
\hline $\operatorname{LSD}(p=0.05)$ & NS & NS & NS & NS & NS & NS \\
\hline \multicolumn{7}{|c|}{ NPK levels (kg ha-1) } \\
\hline $50: 25: 25$ & $36.40 \mathrm{a}$ & $29.24 \mathrm{a}$ & $48.81 \mathrm{~b}$ & $4.14 b$ & $21.94 \mathrm{a}$ & $5.70 \mathrm{a}$ \\
\hline 62.5:31.25:31.25 & $36.22 \mathrm{a}$ & $29.39 a$ & $49.34 \mathrm{a}$ & $4.27 \mathrm{a}$ & $21.94 a$ & $5.60 \mathrm{ab}$ \\
\hline $75: 37.5: 37.5$ & $36.14 \mathrm{a}$ & $29.28 \mathrm{a}$ & $49.66 \mathrm{a}$ & $4.27 \mathrm{a}$ & $21.68 \mathrm{a}$ & $5.53 \mathrm{~b}$ \\
\hline S. E. $(\mathrm{m}) \pm$ & 0.19 & 0.11 & 0.16 & 0.03 & 0.21 & 0.04 \\
\hline $\operatorname{LSD}(p=0.05)$ & NS & NS & 0.45 & 0.08 & NS & 0.12 \\
\hline Mean & 36.25 & 29.30 & 49.27 & 4.23 & 21.85 & 5.61 \\
\hline
\end{tabular}

Means sharing different letters differ significantly at $\mathrm{p} \leq 0.05$

NS: Non significant

\section{Fiber quality parameters}

Table 4 shows fiber quality parameters of cotton in respect of a different treatment under study. Bt cotton hybrid significantly improved the ginning out turn over non-Bt. However, non-Bt cotton recorded significantly higher values of staple length and micronaire than Bt. This result corroborates the findings of Patil et al. (2009) ${ }^{[29]}$. The fiber quality parameters remained unaffected due to spacing. The application of $75: 37.5: 37.5 \mathrm{~kg}$ NPK ha-1 recorded significantly higher values of uniformity ratio and micronaire but was at par with $62.5: 31.25: 31.25 \mathrm{~kg}$ NPK ha-1. Increase in micronaire value with increase in $\mathrm{N}$ level was reported by Saleem et al. (2010) ${ }^{[40]}$. Negative relationship was observed between elongation percentage and NPK level. An application of 50:25:25kg NPK ha-1 recorded significantly maximum elongation percentage but was at par with $62.5: 31.25: 31.25 \mathrm{~kg}$ NPK ha-1. Marked reduction in the elongation percentage at higher levels of NPK was also reported by Halemani et al. (2004) ${ }^{[16]}$.

\section{Conclusion}

This study indicates that Bt cotton hybrid has short physique but have a higher assimilation rate, square formation rate, fruit production efficiency, boll retention efficiency and early in maturity than non-Bt cotton. The Bt cotton produces higher seed cotton yield with maximum ginning out turn but have lower staple length and micronaire value over non-Bt cotton. The cotton plants under lower density i.e. at $90 \times 60 \mathrm{~cm}$ spacing exhibit horizontal growth, have thick leaf, maximum assimilation rate, square formation rate, boll retention efficiency and produce more number of bolls and seed cotton yield per plant than higher plant density i.e. $90 \times 45 \mathrm{~cm}$ spacing. However, higher plant density compensate per plant yield loss by producing maximum seed cotton yield per ha than lower plant density. The plant density did not govern quality parameters of cotton. An application of 75:37.5:37.5kg NPK ha-1 augment growth of cotton plant and improve the rate of square formation, fruit production efficiency, boll retention efficiency, boll growth rate, yield attributes, seed cotton yield per ha and lint qualities viz., uniformity ratio and micronaire value than lower levels. Whereas, for elongation per cent the lowest level i.e. 50:25:25kg NPK ha-1 was promising.

\section{Acknowledgments}

I gratefully acknowledge the Research Scientist, Cotton Research Unit, Dr. Panjabrao Deshmukh Krishi Vidyapeeth (Dr. PDKV), Akola and Head of the Department of Agronomy, Dr. PDKV, Akola for providing the necessary field and lab facilities to accomplish this work.

\section{References}

1. Ansingkar AS, More SS, Bhatade SS, Dhuppe MV, Choudhary MV. Evaluation of transgenic Bt cotton hybrids in comparison with non-Bt and checks in rainfed condition. J. Soils and Crops. 2005; 15(2):338-342.

2. Ashley DA, Doss DB, Bennet OL. A method of determining leaf area in cotton. Agron. J. 1963; 55:584585 .

3. Ayissaa T, Kebedeb F. Effect of nitrogenous fertilizer on the growth and yield of cotton (Gossypium hirsutum L.) varieties in middle Awash, Ethiopia. J Drylands. 2011; 4(1):248-258.

4. Bambawale OM, Jeyakumar P. Dynamics of IPM in fibre crops. In: International Conference on Emerging Trends in Production, Processing and Utilization of Natural Fibres- Book of Papers. Central Institute for Research on Cotton Technology, Mumbai, India, 16-18. 2009; 1:155161.

5. Bhalerao PD, Gaikwad Godavari S. Productivity and profitability of Bt cotton (Gossypium hirsutum) under various plant geometry and fertilizer levels. Indian $\mathrm{J}$. Agronomy. 2010; 55(1):60-63.

6. Bhalerao PD, Patil BR, Gawande PP, Ghatol PU. Response of Bt cotton hybrids to various spacing and fertilizer levels under rainfed condition. PKV Res. J. 2008b; 32(2):282-284.

7. Bhalerao PD, Gawande PP, Ghatol PU, Patil BR. Performance of $\mathrm{Bt}$ cotton hybrids for various spacing under rainfed condition. Agric. Sci. Digest. 2008a; 28(1):54-56.

8. Bondada BR, Oosterhuis DM. Canopy photosynthesis, specific leaf weight, and yield components of cotton under varying nitrogen supply. Journal of Plant Nutrition. 2001; 24(3):469-477.

9. Chen DH, Yang CD, Chen Y, Wu YK. The effects on the boll weight and the source-sink characteristic in 
coordination of nitrogen fertilizer and DPC in Bt transgenic cotton. Cotton Science. 2002; 3:147-150.

10. Crozat Y, Judais V, Kasemsap P. Age-related abscission patterns of cotton fruiting forms: timing of the end of abscission susceptibility in relation to water content and growth of the boll. Field Crops Research. 1999; 64:261272.

11. Deosarkar B, Bhatade SS, Gaikwad AR. Comparative performance of Bt cotton hybrids and their conventional version under rainfed conditions of Maharathwada region. J Cotton Res. Dev. 2004; 22(1):150-152.

12. Gangaiah B, Ahlawat IPS, Babu MBBP. Response of nitrogen fertilization on Bt and non-Bt cotton (Gossypium hirsutum) hybrids. SAARC Journal of Agriculture. 2013; 11(1):121-132.

13. Giri AN, Aundhekar RL, Kapse PS, Suryavanshi SB. Response of $\mathrm{Bt}$ cotton hybrids to plant densities and fertilizer levels. J Cotton Res. Dev. 2008; 22(1):45-47.

14. Gomez KA, Gomez AA. Statistical Procedures for Agricultural Research. 2nd Edition, John Wiley and Sons publishing company, New York, 1984.

15. Hakoomat A, Afzal MN, Dilbaugh Muhammad. Effect of sowing dates and plant spacing on growth and dry matter partitioning in cotton (Gossypium hirsutum L.). Pak. J Bot. 2009; 41(5):2145-2155.

16. Halemani HL, Hallikeri SS, Nandagavi RA, Nooli SS. Performance of Bt cotton hybrids at different levels of fertilizer under protective irrigation. In: Proceedings of International Symposium on Strategies for Sustainable Cotton Production-A Global Vision 2. Crop production. UAS, Dharwad, Karnataka, India, 23-25 Nov, 2004, 153155.

17. Hassan M, Maqsood M, Wajid SF, Ranjha AM. Impact of moisture stress and nitrogen on crop growth rate, nitrogen use efficiency, and harvest index of cotton (Gossypium hirsutum L.). Pak. J Agri. Sci. 2016; 53(1):171-180.

18. Hebbar KB, Rao MRK, Khadi BM. Synchronized boll development of Bt cotton hybrids and their physiological consequences. Current Science. 2007; 93:693-695.

19. ISAAA. Biotech Crops in India: The Dawn of New Era. ISAAA Brief No. 39, International Service for the Acquisition of Agri-biotech Applications (ISAAA), South Asia Office New Delhi, India, 2009, 34.

20. Kalaichelvi K. Bt cotton response to plant geometry and fertilizer levels. J Cotton Res. Dev. 2009; 23(1):96-99.

21. Kaur V, Mishra SK, Singh K, Gill KK, Pal RK. Performance of $B t$ and non $B t$ cotton cultivars under different sowing environment of south western Punjab. J Cotton Res. Dev. 2019; 33(1):93-98.

22. Kerby TA, Buxton DR, Matsuda K. Carbon source-sink relationships within narrow-row cotton canopies. Crop Sci. 1980; 20:208-212.

23. Kumara O, Naik TB, Anandkumar BM. Response of Bt cotton hybrids on planting density and fertility levels on growth and yield. Internat. J Agric. Sci. 2014; 10:421425.

24. Manjunatha MJ, Halepyati AS, Koppalkar BG, Pujari BT. Influence of different plant densities on the growth, yield and economics of Bt cotton (Gossypium hirsutum L.) Genotypes under dryland condition. Karnataka J Agric. Sci. 2010; 23(4):580-583.

25. Mayee CD, Rao MRK. Likely impact of Bt cotton cultivation on production and utilization in India. In: Proceedings of National Seminar on Bt Cotton Scenario with Special Reference to India, UAS, Dharwad, Karnataka, India, 2002, 51-57.

26. Mayee CD, Phundan Singh, Punit Mohan, Agarwal DK. Evaluation of $\mathrm{Bt}$ transgenic intra-hirsutum hybrids for yield and fibre properties. Indian Journal of Agricultural Sciences. 2004; 74(1):746-747.

27. Munir MK, Tahir M, Saleem MF, Yaseen M. Growth, yield and earliness response of cotton to row spacing and nitrogen management. The Journal of Animal and Plant Sciences. 2015; 25(3):729-738.

28. Nagender T, Reddy D, Raji P Leela Rani G Sreenivas K, Surekha et al. Productivity of $\mathrm{Bt}$ and non Bt Cotton (Gossypium hirsutum L.) cultivars as influenced by plant geometry and fertilizer levels. Int. J Curr. Microbiol. App. Sci. 2017; 6(9):3208-3217.

29. Patil DV, Deosarkar DB, Patil SG. Study of Bt and nonBt cotton hybrids for yield and quality characters under normal and delay sown condition. J Cotton Res. Dev. 2009; 23(2):199-203.

30. Pettigrew WT. Physiological consequences of moisture deficit stress in cotton. Crop Science. 2004; 44:12651272.

31. Pettigrew WT, Meredith JR WR, Zeng L. Response of obsolete and modern cotton genotypes to varying plant densities. J Cotton Sci. 2013; 17:253-262.

32. Pettigrew WT, Meredith JR WR. Genotypic variation in physiological strategies for attaining cotton lint yield production. J Cotton Sci. 2012; 16:179-189

33. Prakash AH, Bandyopadyaya KK, Gopalkrishnan N. Growth and biomass portioning in $\mathrm{Bt}$ vs non $\mathrm{Bt}$ cotton hybrids in winter irrigated situation in Southern zone of India. J Indian Soci. Cotton Improv. 2008; 129-142.

34. Rao PM, Alapati S. Bt cotton offers planting at higher plant densities in India. In: Proceedings of World Cotton Research Conference. Lubbock, Texas, USA, 10-14 September, 2007.

(https://wcrc.confex.com/wcrc/2007/techprogram/P1180. HTM)

35. Reddy KR, Davidonis GH, Johnson AS, Vinyard BT. Temperature regime and carbon dioxide enrichment alter cotton boll development and fiber properties. Agronomy Journal. 1999; 91:851-858.

36. Reddy RRP, Kumar DB. Yield and economics of Bt cotton as influenced by spacing and nutritional levels. PKV Res. J. 2010; 34(1):20-22.

37. Rekha GO. A comparative assessment of morpho physiological characters and yield in $\mathrm{Bt}$ and non $\mathrm{Bt}$ cotton hybrids. Karnataka Journal of Agricultural Sciences. 2007; 20(4):87.

38. Sahai S, Rahman S. Mahyco-Monsanto's Bt cotton fails to perform. Current Science. 2003; 85:426-427.

39. Sahito A, Baloch ZA, Mahar A, Otho SA, Kalhoro SA, Ali A et al. Effect of water stress on the growth and yield of cotton crop (Gossypium hirsutum L.). American Journal of Plant Sciences. 2015; 6:1027-1039.

40. Saleem MF, Bilal M, Awais FM, Shahid AQ, Anjum SA. Effect of nitrogen on seed cotton yield and fiber qualities of cotton (Gossypium hirsutum L.) cultivars. The Journal of Animal and Plant Sciences. 2010; 20(1):23-27.

41. Sankaranarayanan K, Praharaj CS, Nalayini $P$, Gopalakrishanan N. Growth, yield and quality of $\mathrm{Bt}$ cotton (Gossypium hirsutum) hybrid under varied planting patterns, NPK levels and seasonal variations. Indian Journal of Agricultural Sciences. 2011; 81(9):8790 . 
42. Singh K, Jindal V, Singh V, Rathore P. Performance of Bt cotton hybrids under different geometrical arrangements. J Cotton Res. Dev. 2007; 21(1):41-44.

43. Sisodia RI, Khamparia SK. American cotton varieties as influenced by plant densities and fertility levels under rainfed conditions. J Cotton Res. Dev. 2007; 21(1):35-40.

44. Sivasubramanian V, Selection at suitable indices for determination of earliness of cotton varieties under rice fallow condition. Madras Agric. J. 1962; 49(4):117-120.

45. Srinivasan G. Agronomic evaluation of Bt cotton hybrids in summer irrigated tract of Southern Tamil Nadu. J Cotton Res. Dev. 2006; 20(2):224-225.

46. Srinivasulu K, Hema K, Prasad NVVSD, Krishana Rao $\mathrm{KV}$. Performance of cotton hybrids under different spacings and nitrogen levels in black cotton soils of coastal Andhra Pradesh. J Cotton Res. Dev. 2006; 20(1):99-101.

47. Tayade AS, Dhoble MV. Dry matter partitioning and plant growth response of transgenic Bt and non Bt cotton. Indian J. Pl. Physiol. 2009; 14(2):47-49.

48. Thakur MR, Gudade BA, Bhale VM. Impact of agronomic intervention and abiotic factors on bollworm infestation in $\mathrm{Bt}$ and non-Bt cotton (Gossypium hirsutum L.) under rainfed condition. Journal of Entomology and Zoology Studies. 2018; 6(5):317-325.

49. Thakur MR, Bhale VM, Mote BM, Wanjari SS. A comparative assessment of crop phenology, agrometeorological indices and yield of $\mathrm{Bt}$ and non-Bt cotton in Akola, Maharashtra. Journal of Agrometeorology. 2017; 19(2):153-155.

50. Wells R, Meredith JR WR. Comparative growth of obsolete and modern cotton cultivars: II. Reproductive dry matter partitioning. Crop Sci. 1984; 24:863-868.

51. Williams RF. Physiological ontogeny in plants and its relation to nutrition.VI. Analysis of the unit leaf rate. Australian Journal of Experiment on Biology and Medical Science. 1946; 17:123-332. 